\title{
HEAVY FUEL ENGINE TECHNOLOGY ASSESSMENT
}

\section{INTERIM REPORT \\ TFLRF No. 331}

\author{
By \\ Cynthia F. Palacios \\ Edwin C. Owens
}

U.S. Army TARDEC Fuels and Lubricants Research Facility (SwRI) Southwest Research Institute

San Antonio, TX

And

Charles D. Wood

CDW Engineering

San Antonio, TX

Under Contract to

U.S. Army TARDEC

Petroleum and Water Business Area

Warren, MI

Prepared for

Defense Advanced Research Projects Agency

3701 N. Fairfax Drive

Arlington, VA

Contract No. DAAK70-92-C-0059

Approved for public release; distribution unlimited

February 1998

DEDO QUATHY INSPECTED 3

19980223048 


\section{Disclaimers}

The findings in this report are not be construed as an official Department of the Army position unless so designated by other authorized documents.

Trade names cited in this report do not constitute an official endorsement or approval of the use of such commercial hardware or software.

\section{DTIC Availability Notice}

Qualified requestors may obtain copies of this report from the Defense Technical Information Center, Attn: DTIC-OCC, 8725 John J. Kingman Road, Suite 0944, Fort Belvoir, Virginia 22060-6218.

\section{Disposition Instructions}

Destroy this report when no longer needed. Do not return it to the originator. 


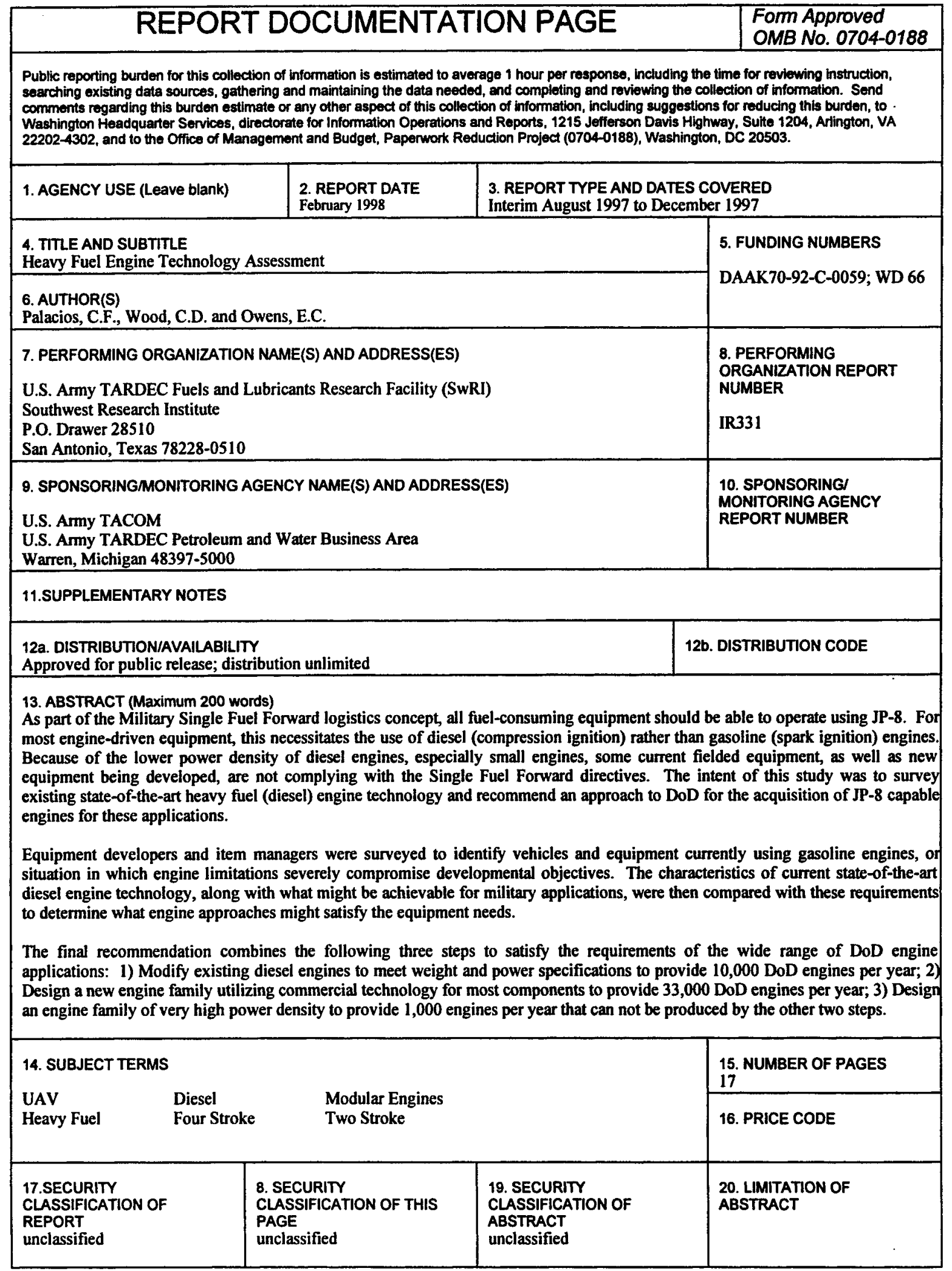




\section{EXECUTIVE SUMMARY}

Objective: There are several heavy fuel (diesel) engines needed for DoD applications, including engines for Unmanned Arial Vehicles (UAVs). The objective of this study was to identify the best approach to acquire those engines.

Importance of Project: The recommendations developed during this study are useful as a starting point for heavy fuel engine acquisition. This report contains a general description of the type of engine needed for each DoD application. The next step would involve the generation of specific program goals from the ideas presented here.

Technical Approach: Initially, several heavy-fuel powerplant options were considered: diesel engines, gas turbine engines, rotary engines and fuel cells. The diesel engine was chosen for further evaluation. Current state-of-the-art diesel engines were surveyed, as well as the specifics of current production models, and an approach was recommended for the acquisition of the needed engines.

Results: Compression ignition engines that satisfy all of the DoD engine needs can be obtained in three steps. Some of the engines can be modified production engines. Most of the engines must be obtained by development of a new four-stroke diesel engine family. This engine family can be based on existing commercial technology. To acquire a smaller number of DoD applications with strict power and weight requirements, a second family of engines can be developed. This family would consist of two-stroke diesels and would have a smaller commercial technology base. Included in this family are the UAV engines. It is estimated that the two engine families can be developed over a period of five years, at a funding level of $\$ 51,000,000$.

Preceding Page Blank 


\section{TABLE OF CONTENTS}

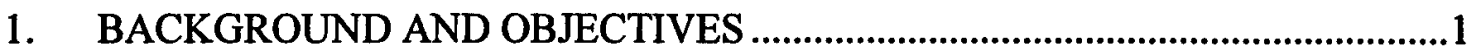

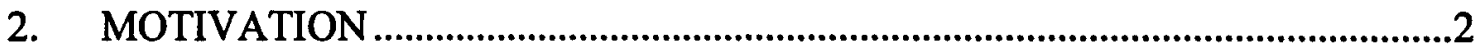

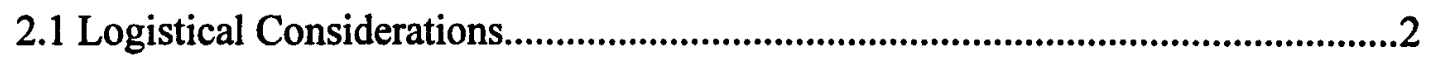

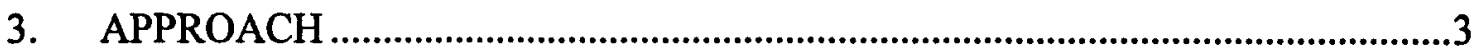

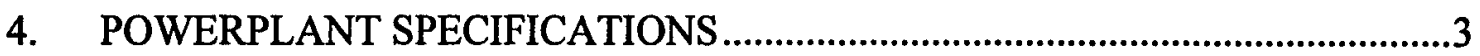

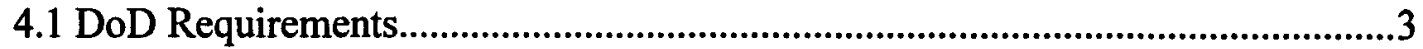

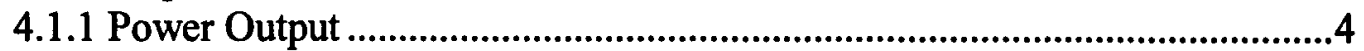

4.1.2 Specific Weight ........................................................................................

4.1.3 Thermal Efficiency ........................................................................................4

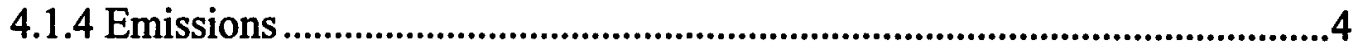

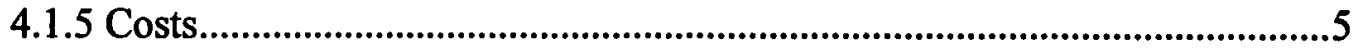

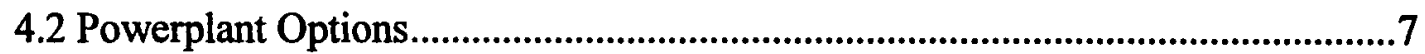

4.2.1 Spark-Assisted Diesel -Reciprocating or Rotary ...........................................8

4.2.2 Gas Turbine Engines................................................................................

4.2.3 Diesel Engines ................................................................................................

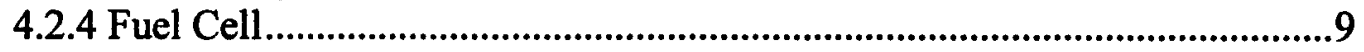

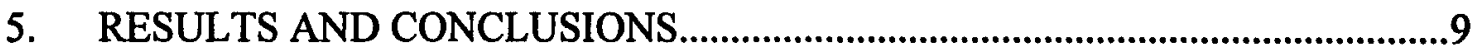

5.1 Modified Commercial Diesel Engines...............................................................9

5.2 Commercially-Based Engine Family ......................................................................11

5.3 DoD-Specific Engine Family..................................................................................14

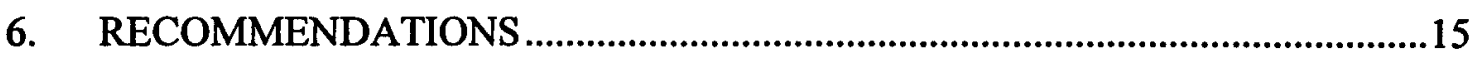

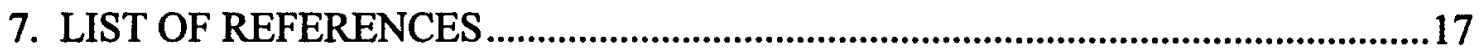

\section{APPENDICES}
A. Engine Duty Cycles
B. Basic Engine Calculations
C. Weight Breakdown of Cummins M11 Engine
D. Development of Commercially Based Engine Family
E. Current Diesel Engine Technology
F. Development of DoD-Specific Engine Family 


\section{LIST OF TABLES}

1. DoD Applications for Heavy Fuel Engines ................................................................6

2. Powerplant Potential to Meet DoD Requirements........................................................7

3. Existing Commercial Engines for Use in DoD Applications .....................................11

4. Government Development Programs in Progress ......................................................12

5. Commercially-Based Engine Family, PNGV Power Section....................................13

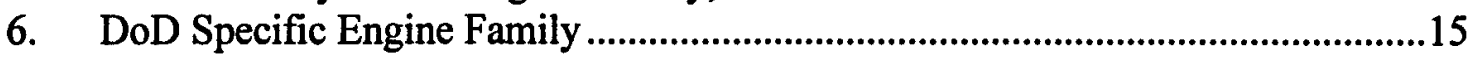

\section{LIST OF FIGURES}

1. Development Program Outline ...........................................................................17 


\section{BACKGROUND AND OBJECTIVES}

The Department of Defense requires a wide variety of engines to be used as powerplants for new or enhanced applications. In compliance with the "Single Fuel Forward" concept, these engines must operate on JP-8 or diesel fuel. The applications for these engines require small and lightweight power sources. This project involved a survey and analysis of state-of-the-art heavy fuel engine (HFE) technology. Heavy fuel engines identified by this study fulfilled a wide variety of requirements based on technical, cost, and logistical criteria. The result of this project is a strategy for acquiring the needed heavy fuel engines.

To gain information and insight into the HFE technology currently available, a Program Advisory Group (PAG) was established. This group consisted of recognized experts in vehicle fuels, diesel engine technology, and gas turbine engine technology. Additionally, the PAG received input from various industry and government sources. PAG membership consisted of the following:

Defense Advanced Research Projects Agency

John Gully, Chairman

Office of the Secretary of Defense

Joe Eash

John Fricas

Department of Energy

Bill Siegel

Defense Airborne Reconnaissance Office

John Entzminger

Robert Dutterer

NAVAIR

Wayne Parsons

NAVSEA

Sam Shepard
NASA-Langley Burt Northam

Army Tank-Automotive Command

Walter Bryzik

Charles Raffa

Industrial Consultants

Charles D. Wood, CDW Engineering Mark Rice, MAPC

Ed Owens, Southwest Research Institute Ira F. Kuhn, Jr, Directed Technologies Gary Rogers, FEV 


\section{MOTIVATION}

\subsection{Logistical Considerations}

In 1988, the Department of Defense issued a directive (1) ${ }^{1}$ stating that Military Services will develop and acquire new systems based only on diesel and turbine (JP-5/JP-8) fuels (2). This policy is part of the "Single Fuel Forward" concept of supplying only JP-8 fuels during overseas combat. The remaining gasoline engines within DoD combat and technical equipment require that a small amount of gasoline continue to be stocked, complicating the fuel supply process.

Aviation Gasoline (AVGAS) is particularly difficult to obtain. It is no longer stocked in the military system, so outside sources in the open market must continually be located. The quality of AVGAS locally purchased at various worldwide locations may vary, impacting engine operation. In addition, when AVGAS must be transported, the 55gallon drum containers require special handling, from procurement to use and disposal. Special handling equipment (forklifts and fueler/defueler pumps) is required to move and transfer the fuel from the 55-gallon drums to support ground-based operations. The ability to transfer and move fuel (tankers, fuel bladders, and pumps) without possible contamination is impacted. Separate fuel pits are required to segregate the highly flammable fuel.

The low flashpoint of gasoline makes it readily flammable and explosive. This is especially dangerous at sea where a fire cannot be readily escaped. A special fuel bladder must be installed on ships to allow the gasoline to be stored outside the ship on a jettisonable rack. In case of fire, this bladder can be jettisoned, thereby reducing the danger of adding fuel to another fire or of the fuel igniting. However, once a bladder is jettisoned, there is no gasoline supply for further operations. The disposal of empty fuel drums, with the associated explosive hazard, is also difficult. Once all of these hazards

\footnotetext{
' Underscored numbers in parentheses refer to the list of references at the end of this report.
} 
are considered, the ability to operate on JP-8 or JP-5 shipboard substantially increases handling safety.

\section{APPROACH}

The intent of this study was to survey existing state-of-the-art heavy fuel (diesel) engine technology and recommend an approach to DoD for the acquisition of JP-8 capable engines for these applications.

Equipment developers and item managers provided information on engines needed by DoD. They were surveyed to identify vehicles and equipment currently using gasoline engines or situations where engine limitations severely compromised developmental objectives. The characteristics of current state-of-the-art diesel engine technology, along with what might be achievable for military applications, were then compared with these requirements to determine what engine approaches might satisfy the equipment needs.

Initially, several heavy-fuel powerplants were considered, including gas turbine engines, diesel engines, spark-assisted diesel engines, and fuel cells. The potential for each powerplant to meet DoD engine needs was considered, and the diesel engine was determined to be the most suitable for the DoD applications. Diesel engine technology was then examined more closely, and an approach for the acquisition of the needed engines was developed.

\section{POWERPLANT SPECIFICATIONS}

\subsection{DoD Requirements}

This study targets 19 DoD engine applications that are either currently powered by gasoline-fueled, spark-ignition engines, or are new requirements. Specifications for the applications addressed in this study are listed in Table 1. 
Some of these applications were developed around existing gasoline engines and require any replacement powerplant to have similar weight and size. Power output must be similar to avoid compromising performance. In all applications, fuel-consumption requirements have been set at or near the diesel state-of-the-art because of DoD 's objective to minimize the logistic burden of fuel supply.

\subsubsection{Power Output}

The applications listed in Table 1 require power outputs from 24 to $440 \mathrm{hp}$. In each case, the power requirement listed is the continuous power need. In the UAV cases, maximum power needs may be higher.

\subsubsection{Specific Weight}

The most significant characteristic of this set of applications is the required low weight per horsepower (specific weight), which ranges from 1.3 to $4.2 \mathrm{lb} / \mathrm{hp}$. In almost every case, meeting the specific weight requirements requires pushing current technology to its limits.

\subsubsection{Thermal Efficiency}

All applications of Table 1 require a thermal efficiency greater than 35 percent, with the maximum requirement about 40 percent. These levels are within current diesel capabilities.

\subsubsection{Emissions}

Almost all of the applications listed in Table 1 are required to meet EPA emissions requirements for NOx, hydrocarbons, $\mathrm{CO}$, and particulates. Those that aren't are limited in the amount of allowable visible smoke. 


\subsubsection{Costs}

The needs addressed by this study comprise a relatively small number of powerplants; therefore, the unit cost promises to be high. The best solution to this problem is to identify commercial powerplants already in production that can be modified with relative ease to meet the DoD requirements. Failing this, the next best solution is to use the concept of "modularity," where a number of powerplants for different applications use a large number of common systems or sub-systems so that design, development, and production costs are reduced. An additional advantage of modularity is the reduction of replacement parts in inventory, which reduces logistical costs. A complete discussion of the cost savings possible through modularity can be found in "Cost Implications of a Common Engine." (3) 


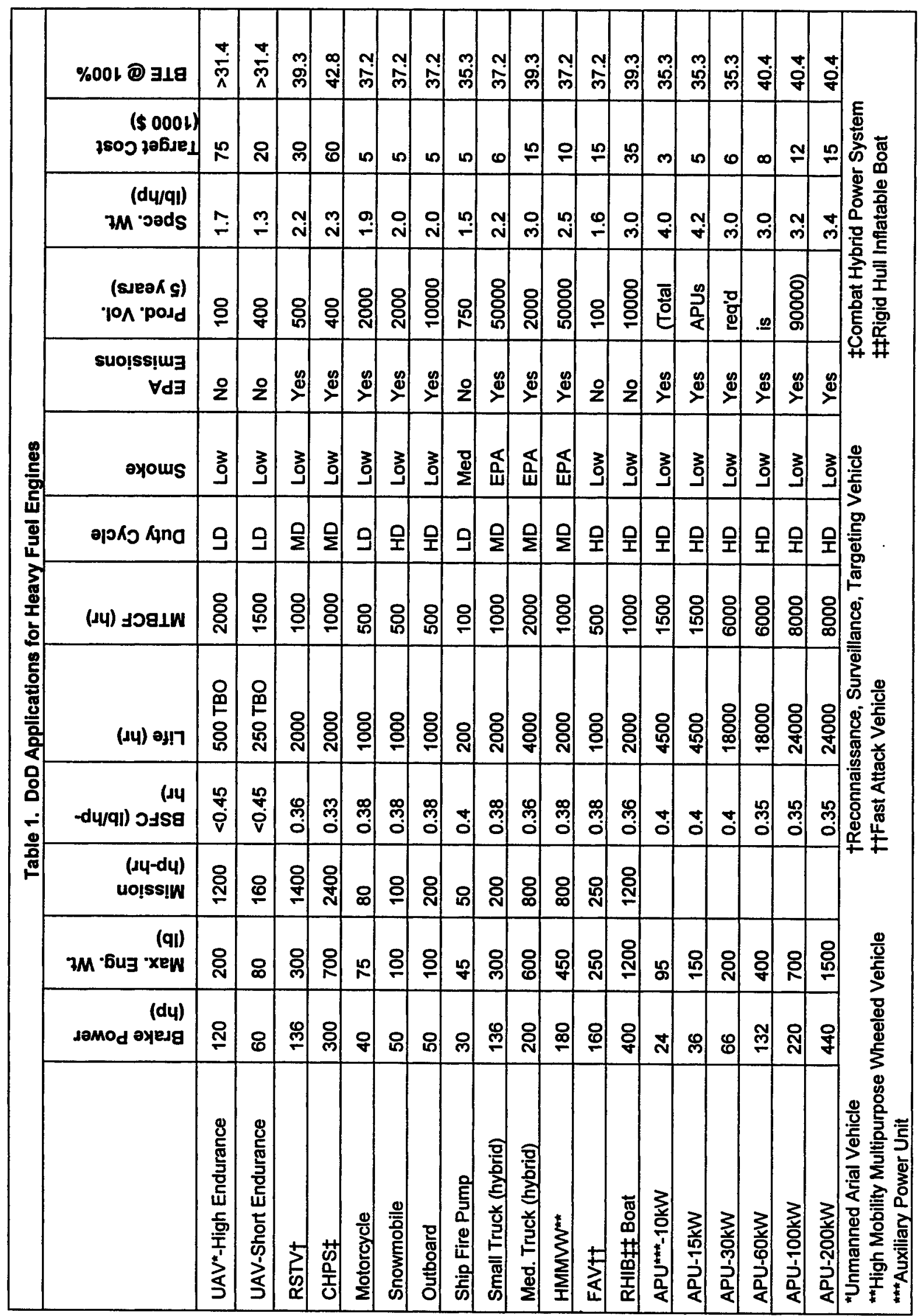




\subsection{Powerplant Options}

The powerplants evaluated were gas turbine engines, spark-assisted diesel engines (reciprocating and rotary), diesel engines, and fuel cells. The following criteria were used to evaluate the powerplants:

1. Is the best current technology capable of producing powerplants with operational characteristics reasonably close to DoD requirements?

- Power Output

- Specific Weight $(\mathrm{lb} / \mathrm{hp})$

- Thermal Efficiency

- Emissions

- Durability/Reliability

2. Can unit cost be reasonably close to DoD requirements?

3. Are commercial production powerplants available for any of the DoD applications?

4. Is the powerplant configuration amenable to modular construction?

Consideration of these questions is shown in Table 2.

\begin{tabular}{|c|c|c|c|c|c|}
\hline \multirow{2}{*}{$\begin{array}{c}\text { Can Target } \\
\text { Be Met? }\end{array}$} & \multirow[b]{2}{*}{ Gas Turbine } & \multicolumn{2}{|c|}{ Spark-Assisted } & \multirow[b]{2}{*}{ Diesel } & \multirow[b]{2}{*}{ Fuel Cell } \\
\hline & & Reciprocating & Rotary & & \\
\hline Power Output & $\begin{array}{l}\text { Only for } \\
\text { highest } \\
\text { power needs }\end{array}$ & Yes & Yes & Yes & $\begin{array}{l}\text { Only for } \\
\text { Highest } \\
\text { power needs }\end{array}$ \\
\hline Specific Weight & Yes & Probably & Probably & Probably & No \\
\hline Efficiency & No & Unknown & Unknown & Yes & Yes \\
\hline Emissions & Yes & Very doubtful & Very doubtful & Yes & Yes \\
\hline $\begin{array}{l}\text { Durability/ } \\
\text { Reliability }\end{array}$ & Yes & Unknown & Unknown & Yes & Yes \\
\hline $\begin{array}{l}\text { Commercial } \\
\text { Production? }\end{array}$ & $\begin{array}{l}\text { Only in } \\
\text { high powers }\end{array}$ & No & No & Yes & No \\
\hline $\begin{array}{l}\text { Modularity } \\
\text { Possible? }\end{array}$ & No & Yes & Yes & Yes & Maybe \\
\hline $\begin{array}{l}\text { Meet Cost } \\
\text { Targets? }\end{array}$ & No & Maybe & Maybe & Maybe & No \\
\hline
\end{tabular}


The comments in Table 2 are, to some degree, subjective. An explanation of those comments follows.

\subsubsection{Spark-Assisted Diesel - Reciprocating or Rotary}

This engine has the ability to produce the required horsepower for the various DoD applications, but no previous design has proven that the specific weight, efficiency, emissions, or durability targets can be met. For instance, we believe that it would be very difficult to meet the emissions targets because of the primary need in this engine to coordinate spark and fuel injection. This coordination eliminates design flexibility needed for emissions control.

\subsubsection{Gas Turbine Engine}

Gas turbine technology is not available for the smaller power needs of the DoD. For the highest power needs, the specific weight targets can easily be met if the engine is not recuperated. ${ }^{2}$ If it is, then the number of applications that can be satisfied are further decreased. According to turbine developers, full load efficiency targets can be met with recuperated engines, but part-load efficiency is not impressive and falls well under the diesel engine. There is little or no commercial production, and it is difficult to see how modular engines could be devised. There is no realistic indication that any of the cost targets can be met.

\subsubsection{Diesel Engine}

Power, efficiency, emissions, and durability targets can be met, and it appears from the following analysis that specific weight targets can also be met. A few engines that are close to the DoD requirements are commercially produced, and more importantly, commercial technology that can be applied directly to our problem is available from

\footnotetext{
${ }^{2}$ In a recuperated turbine engine, exhaust air is directed through a heat exchanger to raise the temperature of compressed intake air. Thus, energy in the exhaust is recirculated and conserved, and overall engine efficiency is increased.
} 
many sources. Modularity is possible, and the cost targets can be met if full use is made of commercial production and technology.

\subsubsection{Fuel Cell}

The PAG did not encounter any viable fuel cells that could be produced to burn JP-8 and diesel fuel. Very low-power fuel cells seem unlikely, but the highest DoD power needs could probably be satisfied. However, current technology offers no possibility of meeting the specific weight requirements, although (given a large and heavy fuel cell and successful heavy fuel technology) the requirements for efficiency, emissions, and durability could probably be met. Given the lack of commercial experience and technology, it seems unlikely that the cost targets could even be approached.

\section{RESULTS AND CONCLUSIONS}

For the reasons discussed in Section 4, the diesel was selected as the powerplant to satisfy the DoD requirements, and no further consideration was given to the other powerplant types.

\subsection{Modified Commercial Diesel Engines}

To find existing commercial engines that might fit a DoD application, Southwest Research Institute's Engine Research Database as well as Power Systems Inc.'s EnginLink database were used. Both of the databases contained detailed and up-to-date specifications for the majority of the compression-ignition engines that are manufactured worldwide. Upon comparison of the two databases, it was found that they contained similar information with few minor differences.

The engine database was searched to find existing engines that matched the specifications set for each of the DoD applications in Table 1. The following fields were used to determine whether or not an engine "matched": output power, engine weight, and duty 
cycle. If an existing engine had at least 75 percent of the specified output power, less than 133 percent of the specified engine weight, and the same (or a more severe) duty cycle as the DoD applications, it was considered to be a match for that application. For an explanation of duty cycle requirements, see Appendix A. By using those search criteria, three commercial engines were identified. Each of these engines had lower power and greater weight than required by DoD. The possibility of making modifications to these engines so that they would meet the specifications was then considered. Only three matches were found because 1) commercial engines were heavier than DoD requires, 2) few manufacturers produce diesels in the power range needed, and 3) of those that were found in the right power range, many were light-duty engines, and a heavy or medium duty engine is often required.

Power output can be increased with increased turbocharging. It was estimated that the maximum power increase is approximately 25 percent $^{3}$. This value was chosen using experience with the effects of power increase on engine life and durability.

Weight can be reduced by the use of lighter materials. For a commercial engine with cast iron cylinder block and heads, the weight reduction that can be achieved by substituting aluminum block and heads is approximately 22 percent. If the engine has a cast iron block but aluminum heads, the weight reduction is about 16 percent. These weight reduction estimates are based on the analysis of the weights of the components of a Cummins M11 diesel engine (details are presented in Appendix C).

It was found that modified commercial engines could replace only the 15, 100, and 200 kW Auxiliary Power Unit (APU) engines. The requirement for these three applications is 10,000 engines per year. The specifications for these engines and the modifications that would be required are shown in Table 3. An American manufacturer makes only one of these engines.

\footnotetext{
${ }^{3}$ If the Brake Mean Effective Power (BMEP) of that engine were already above $200 \mathrm{psi}$, it would not be safe to boost it by the full 25 percent. For an explanation of the relationship between BMEP and output power, see Appendix B.
} 


\begin{tabular}{|c|c|c|c|c|c|c|c|c|c|c|c|c|}
\hline $\begin{array}{l}\text { Engine } \\
\text { Mfg. }\end{array}$ & $\begin{array}{l}\text { No. } \\
\text { of } \\
\text { Cyl }\end{array}$ & $\begin{array}{l}\text { Bore } \\
\text { (in) }\end{array}$ & $\begin{array}{l}\text { Stroke } \\
\text { (In) }\end{array}$ & $\begin{array}{l}\text { Disp } \\
\left(i^{3}\right)\end{array}$ & $\begin{array}{l}\text { Pwr } \\
\text { (hp) }\end{array}$ & RPM & $\begin{array}{l}\text { 8MEP } \\
\text { (psi) }\end{array}$ & $\begin{array}{l}w_{t} \\
\text { (b) }\end{array}$ & $\begin{array}{l}\text { Spoc. } \\
\text { Wt } \\
(\mathrm{fb} / \mathrm{hp})\end{array}$ & $\begin{array}{l}\text { Duty } \\
\text { Cycle }\end{array}$ & $\begin{array}{l}\text { Wh. } \\
\text { De- } \\
\text { crease }\end{array}$ & $\begin{array}{l}\text { Power } \\
\text { In- } \\
\text { crease }\end{array}$ \\
\hline $\begin{array}{l}\text { APU- } \\
15 \mathrm{~kW}\end{array}$ & & & & & 36 & & & 150 & 4.17 & $\mathrm{HD}$ & & \\
\hline $\begin{array}{l}\text { Kubota } \\
\text { V800-TB }\end{array}$ & 4 & 2.52 & 2.44 & 49 & 34 & 4500 & 122.6 & 165 & 4.85 & $\overline{H D}$ & $9.1 \%$ & $5.9 \%$ \\
\hline $\begin{array}{l}\text { APU- } \\
100 \mathrm{~kW}\end{array}$ & & & & & 220 & & & 700 & 3.18 & HD & & \\
\hline $\begin{array}{l}\text { Navistar } \\
\text { T444E }\end{array}$ & 8 & 4.11 & 4.18 & 444 & 215 & 3000 & 127.9 & 930 & 4.33 & $H D$ & $24.7 \%$ & $2.3 \%$ \\
\hline $\begin{array}{l}\text { APU- } \\
200 \mathrm{~kW}\end{array}$ & & & & & 440 & & & 1500 & 3.41 & HD & & \\
\hline $\begin{array}{l}\text { Iveco } \\
\text { AlFO } \\
8460.41\end{array}$ & 6 & 4.72 & 5.51 & 580 & 370 & 2100 & 240.8 & 1900 & 5.13 & $\mathrm{HD}$ & $21.0 \%$ & $18.9 \%$ \\
\hline
\end{tabular}

Although these three engines already exist, there would be some technical risk in modifying them to the degree required. Increasing the power output (and therefore the cylinder pressure) of an engine will increase the stress on that engine during operation, and reduce its durability. Durability is reduced again by the substitution of light components for heavier ones. However, these engines will be used as powerplants for APUs, which require engines with long life. Substantial development work will be required to make substantial power and weight changes without affecting durability.

\subsection{Commercially Based Engine Family}

Modified commercial engines can only be used for three of the $19 \mathrm{DoD}$ applications. To fulfill the engine requirements of the other 16 applications, new engines will have to be developed. In compliance with our objectives, the PAG focused on the development of a single engine family to satisfy as many of the DoD requirements as possible.

Several diesel engine development programs sponsored by different government and industry groups are currently in progress (Table 4). The small, high-power-density diesel engines that result from these programs will have power sections that are candidates for a modular engine family. 


\begin{tabular}{|l|l|l|l|l|l|l|}
\hline \multicolumn{7}{|c|}{ Table 4. Government Development Programs in Progress } \\
\hline Program Name & Sponsor & Contractors & $\begin{array}{l}\text { Power } \\
\text { Level } \\
(\mathrm{hp})\end{array}$ & $\begin{array}{l}\text { Power } \\
\text { Density } \\
\text { (lb/hp) }\end{array}$ & $\begin{array}{l}\text { Funding } \\
\text { Level }\end{array}$ & $\begin{array}{l}\text { Completion } \\
\text { Year }\end{array}$ \\
\hline $\begin{array}{l}\text { Sport Utility } \\
\text { Vehicle }\end{array}$ & $\begin{array}{l}\text { DOE \& } \\
\text { Industry }\end{array}$ & $\begin{array}{l}\text { Caterpillar, } \\
\text { Cummins, } \\
\text { DDC }\end{array}$ & $200-250$ & 2.5 & $\begin{array}{l}\$ 165 \mathrm{M} \\
5 \text { years }\end{array}$ & 2002 \\
\hline $\begin{array}{l}\text { Partnership for a } \\
\text { New Generation } \\
\text { of Vehicles }\end{array}$ & $\begin{array}{l}\text { DOE \& } \\
\text { Industry }\end{array}$ & $\begin{array}{l}\text { Ford, GM, } \\
\text { Chrysler }\end{array}$ & $60-90$ & 2 & $\begin{array}{l}\$ 100 \mathrm{M} \\
5 \text { years }\end{array}$ & 1998 \\
\hline $\begin{array}{l}\text { General Aviation } \\
\text { Program }\end{array}$ & $\begin{array}{l}\text { NASA \& } \\
\text { Industry }\end{array}$ & $\begin{array}{l}\text { Teledyne } \\
\text { Continental }\end{array}$ & 200 & $<1.5$ & $\begin{array}{l}\$ 1.9 \mathrm{M} \\
3 \text { years }\end{array}$ & 2000 \\
\hline $\begin{array}{l}\text { UAV Exploratory } \\
\text { Development }\end{array}$ & DARO & $\begin{array}{l}\text { ECA, FEV, } \\
6 \mathrm{~A}\end{array}$ & $120-160$ & $1-1.5$ & $\$ 2 \mathrm{M}$ & 1998 \\
\hline
\end{tabular}

If the cylinder bore diameter of the power cylinder of an engine family is known, as well as the rated piston speed and the engine weight per unit volume of piston displacement, the power and weight characteristics of an entire modular engine family can be determined. In the interest of utilizing commercial components and technology, the power cylinder of the DoD engine family was chosen from among the engines of Table 4. The third and fourth engines listed in this table were eliminated from consideration because they both employ two-stroke cycles for which little commercial production or technology exists. The remaining two (the SUV and PNGV) were evaluated as modular engine family candidates, because they are four stroke engines using state-of-the-art technology for high efficiency, emissions control, and lightweight. The PNGV engine was determined to be the better candidate, primarily because of its smaller bore diameter (estimated as $3.01 \mathrm{in}$.), which results in a lower specific weight than the SUV engine (with a bore diameter of $3.8 \mathrm{in}$.). Details of the assumptions and calculations used to project engine family characteristics are presented in Appendix D.

Rated piston speed of the PNGV engine is estimated to be $2300 \mathrm{fpm}$. While the PNGV engine is not yet designed, state-of-the-art, high-speed, direct-injection (DI) diesel engines can achieve a volume-specific weight of 1.9 pounds per cubic inch of displacement, as found in our databases, if aluminum blocks and head are used. The volume-specific weight is largely independent of the number of cylinders and is an 
attribute of the engine design, including the power section design. Therefore, all the engines in a modular family will have the same volume-specific weight, which in this case is $1.9 \mathrm{lb} / \mathrm{in}^{3}$.

It was found that a modular engine family with a 3.01 in. cylinder bore diameter, a piston speed of $2300 \mathrm{fpm}$, and a volume-specific weight of $1.9 \mathrm{lb} / \mathrm{in}^{3}$ would satisfy 13 of the remaining $16 \mathrm{DoD}$ applications. This amounts to the production of 33,000 engines per year. As can be seen from Table 5, this engine family would range in power output from 24 to $400 \mathrm{hp}$, and in specific weight from 1.2 to $3.7 \mathrm{lb} / \mathrm{hp}$. These are very low weight-topower ratios. Currently, the specific weight is no lower than $2.8 \mathrm{lb} / \mathrm{hp}$ in the most advanced commercial engines. Information on current commercial diesel engine technology can be found in Appendix E. However, at the rated horsepower, the Brake Mean Effective Pressure (BMEP) of some of the engines in this modular family must be as high as 270 psi to produce the specific weight shown in Table 5. If the BMEP of an engine in this family is lowered while maintaining the specification power level and using the modular power section, the number of cylinders must be increased. This will increase the specific weight $(\mathrm{lb} / \mathrm{hp})$.

\begin{tabular}{|l|l|l|l|l|}
\hline \multicolumn{5}{|c|}{ Table 5. Commercially-Based Engine Family, PNGV Power Section } \\
\hline Application & $\begin{array}{l}\text { Output Power } \\
\text { (hp) }\end{array}$ & $\begin{array}{l}\text { Number of } \\
\text { Cylinders }\end{array}$ & $\begin{array}{l}\text { lMEP } \\
\text { (psi) }\end{array}$ & $\begin{array}{l}\text { Specific Weight } \\
\text { (b/hp) }\end{array}$ \\
\hline UAV-High Endurance & 120 & 4 & 245 & 1.34 \\
\hline RSTV & 136 & 5 & 220 & 1.46 \\
\hline CHPS & 300 & 10 & 240 & 1.34 \\
\hline Snowmobile & 50 & 2 & 200 & 1.64 \\
\hline Outboard & 50 & 2 & 200 & 1.64 \\
\hline Small Truck (hybrid) & 136 & 5 & 220 & 1.46 \\
\hline Medium Truck (hybrid) & 200 & 6 & 270 & 1.22 \\
\hline HMMWW & 180 & 6 & 240 & 1.37 \\
\hline FAV & 160 & 5 & 260 & 1.26 \\
\hline RHIB Boat & 400 & 12 & 270 & 1.24 \\
\hline APU-10kW & 24 & 2 & 95 & 3.65 \\
\hline APU-30kW & 66 & 3 & 180 & 1.82 \\
\hline APU-60kW & 132 & 5 & 215 & 1.56 \\
\hline
\end{tabular}


In order to realize the specifications of Table 5 , this modular engine family must incorporate state-of-the-art technology relating to all aspects of the diesel engine. This would include:

- Four valves/cylinder

- High pressure, common rail fuel injection

- Highly developed air/fuel mixing

- Turbocharged and intercooled

- Variable geometry turbocharger

- Light alloy components (cylinder head, block, rods and housings)

- Low friction valve gear

- Reduced heat flow to coolant

- Exhaust aftertreatment and EGR, depending on turbine emissions standards

\subsection{DoD-Specific Engine Family}

The three DoD applications remaining (Short Endurance UAV, Motorcycle, and Ship Fire Pump) cannot be satisfied by either a modified commercial engine or the commercially based engine family. These applications have low power requirements as well as very low specific weight requirements, which could not be obtained with the commercially based power section.

The low specific weight of the remaining three DoD engine applications suggests a twostroke diesel cycle rather than a four-stroke. The two-stroke engine has long been a recognized solution for UAV and motorcycle applications. Various two-stroke cylinder sizes were investigated. The rated piston speed was taken as $2300 \mathrm{fpm}$. Liquid cooling was chosen for this family, because it is believed that the higher BMEP possible with liquid cooling will more than offset the weight penalty (about $0.2 \mathrm{lb} / \mathrm{hp}$ ) associated with coolant, radiator, fan (not required in the UAV), and coolant pump. It was estimated that the volume-specific weight can be as low as $1.42 \mathrm{lb} / \mathrm{in}^{3}$ displacement, therefore this was the value chosen. This power section is not, nor probably ever will be, commercially designed and is therefore a "DoD-Specific" power section. 
Table 6 shows the resulting engine family. To insure that both UAV engines in the DoD requirements have a large degree of commonality, the High Endurance UAV engine (which was originally included in the commercially based engine family) was moved over into the DoD-Specific family.

\begin{tabular}{|l|l|l|l|l|}
\hline \multicolumn{5}{|c|}{ Table 6. DoD-Specific Engine Family } \\
\hline \multicolumn{2}{|c|}{ (2-stroke DI diesel, 2.75 in. bore diameter, 2300 fpm piston speed, 1.42 $\mathrm{lb} / \mathrm{in}^{3}$ disp.) } \\
\hline Application & Output Power (hp) & $\begin{array}{l}\text { Number of } \\
\text { Cylinders }\end{array}$ & BMEP (psi) & $\begin{array}{l}\text { Specific Wt. } \\
\text { (lb/hp) }\end{array}$ \\
\hline UAV-High Endurance & 120 & 3 & 195 & 0.59 \\
\hline UAV-Short Endurance & 60 & 2 & 145 & 0.75 \\
\hline Motorcycle & 40 & 2 & 100 & 1.12 \\
\hline Ship Fire Pump & 30 & 2 & 75 & 1.50 \\
\hline
\end{tabular}

There are only two engines in this engine family, a two-cylinder and a three-cylinder. The total yearly number of engines required from this family is less than 1,000. Power output for the engines ranges from 30 to 120 horsepower. The specific weights that result from combining these engines into a family are very low, dropping to $0.6 \mathrm{lb} / \mathrm{hp}$ for the High-Endurance UAV. These low specific weights might be questioned. If so, two factors should be analyzed for feasibility: the BMEP used for the specific engine under scrutiny and the volume-specific weight $\left(1.42 \mathrm{lb} / \mathrm{in}^{3}\right)$ used for all the engines. At the same time, the small bore diameter makes lower specific weights possible. As bore diameter decreases at a constant piston speed, the engine speed (RPM) increases and specific weight (lb/hp) decreases. In other words, to obtain a given power with the minimum weight at a given BMEP, reduce the bore diameter and increase the number of cylinders.

\section{RECOMMENDATIONS}

In order to obtain heavy fuel engines that meet the specifications of all of the DoD applications in Table 1, it is recommended that the following three steps be taken: 
Modify Existing Commercial Engines

- Three DoD applications satisfied by this step

- 10,000 engines per year

- Modifications feature reduced weight and increased power

- Durability may be reduced

- Relatively low cost and low risk

Develop a Commercially Based Engine Family

- $12 \mathrm{DoD}$ applications satisfied by this step

- 33,000 engines per year

- Commercially based power section common to all family members

- Common fuel injection and power section

- Number of cylinders different for different power needs

- Technical goals:

- Engines will have specified specific weight (1.2 to $3.7 \mathrm{lb} / \mathrm{hp}$ )

- Thermal efficiency greater than $40 \%$

- More than $40 \%$ of engine from commercial components

- Will meet emissions requirements

\section{Develop a DoD-Specific Engine Family}

- Four DoD applications satisfied by this step

- Less than 1,000 engines per year

- Required for highest power density needs, including UAV's

- Modular family with common power section

- Technical goals:

- Engines will have less than $1.5 \mathrm{lb} / \mathrm{hp}$

- Thermal efficiency of $40 \%$

- About $20 \%$ of engine from commercial components

- High cost and high risk 
These three steps are independent. However, the development of a commercially based engine family would benefit from waiting until completion of the other government engine-development programs in progress. The new technology developed in those programs will help reduce the cost and risk of the development work of the commercially based engine family. It is recommended that development of the DoD-specific engine family be undertaken first. A recommended development program outline is shown in Figure 1.

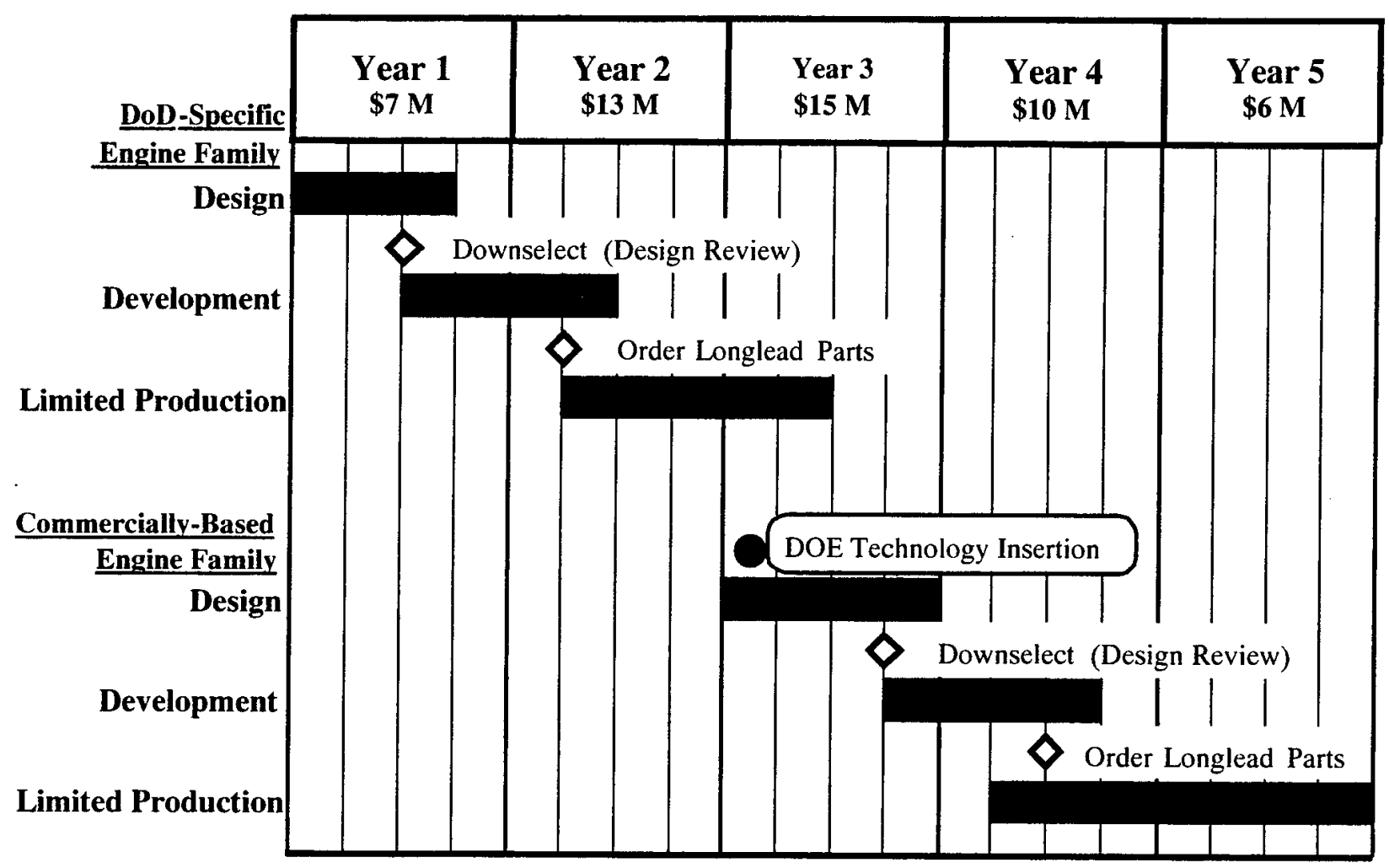

Figure 1. Development Program Outline

\section{LIST OF REFERENCES}

1. Department of Defense Directive 4140.43, subject: "Fuel Standardization," March 1988.

2. Military Specification MIL-T-83133C, "Turbine Fuels, Aviation Kerosene Types," NATO F-34 (JP-8) and NATO F-35, 22 March 1990.

3. TACOM Cost Analysis Division, "Cost Implications of a Common Engine" 
APPENDIX A

Engine Duty Cycles

A-1 
Engines can be divided into one of three categories based the duty cycle they were designed for. If a light duty engine were used in an application that required it to operate under a medium or heavy duty cycle, the life of the engine would be significantly shortened.

- Light Duty (LD) Engines:

- Mostly used in automobile service

- Spend $80 \%$ of life below $50 \%$ power

- Less than $1 \%$ of life spent at full load

- Heavy Duty (HD) Engines:

- Commercial truck, marine, and genset applications

- $80 \%$ of life spent above $50 \%$ power

- $10 \%$ of life spent at idle

- Medium Duty (MD) Engines:

- Between light and heavy duty engines 


\section{APPENDIX B}

Basic Engine Calculations

B-1 
Common variables:

BMEP Brake Mean Effective (Cylinder) Pressure

P Brake horsepower (bhp)

N Rotational Speed of Crankshaft (RPM)

$\mathrm{V}_{\mathrm{D}} \quad$ Volume Displacement of engine (in $\left.{ }^{3}\right)$

$\mathrm{M} \quad$ Weight of Engine (lb)

$n_{s} \quad$ Revolutions per Cycle (1 for 2-stroke engines, 2 for 4-stroke engines)

$\mathrm{S}_{\mathrm{p}}^{\mathrm{s}} \quad$ Piston Speed (fpm)

$\mathrm{S}_{\mathrm{t}}^{\mathrm{p}} \quad$ Piston Stroke (in)

SW Specific Weight of Engine (lb/hp)

VSW Volume Specific Weight of Engine $\left(\mathrm{lb} / \mathrm{in}^{3}\right)$

Relationship between BMEP, power, engine speed, and displacement:

$$
B M E P=\frac{P \times 396,000 \times n s}{V_{D} \times N}
$$

Piston Speed:

$$
S_{p}=\frac{S_{t} \times N}{6}
$$

Specific Weight of Engine:

$$
S W=\frac{M}{P}
$$

Volume Specific Weight of Engine:

$$
V S V=\frac{M}{V_{D}}
$$

BMEP using specific weight and specific volume:

$$
B M E P=\frac{V S W \times 396,000 \times n s}{S W \times N}
$$


APPENDIX C

Weight Breakdown of Cummins M11 Engine

C-1 
A Cummins M11 Engine was torn down and each component weighed. Calculations were done to determine the weight savings possible by substituting lighter materials for some of the heavier components, including the cylinder block and heads, rods, and housings. The criterion for material substitution was that the original stiffness of the component be maintained.

The original and modified weights of the components of the M11 engine are shown in the Table C-1 below.

\begin{tabular}{|l|l|l|}
\hline \multicolumn{3}{|l|}{ Table C-1. Potential Weight Modifications of Cummins M11 Engine } \\
\hline Component & $\begin{array}{l}\text { Original } \\
\text { Weight }(\mathrm{lb})\end{array}$ & $\begin{array}{l}\text { Modified Weight } \\
\text { (lb) }\end{array}$ \\
\hline Cylinder Block & 492 & 261 \\
\hline Cylinder Head & 228 & 121 \\
\hline Housings & 184 & 98 \\
\hline Rods & 56 & 44 \\
\hline Crankshaft & 235 & Not modified \\
\hline Camshaft & 57 & Not modified \\
\hline Pistons & 40 & Not modified \\
\hline Valves \& valve gear & 94 & Not modified \\
\hline FIE \& drive gear & 66 & Not modified \\
\hline Cylinder liners & 71 & Not modified \\
\hline Flywheel & 86 & Not modified \\
\hline Wrist pins & 18 & Not modified \\
\hline Bearings and caps & 48 & Not modified \\
\hline Balancer & 32 & Not modified \\
\hline Gears \& pulleys & 29 & Not modified \\
\hline Brackets, supports, \& bolts & 39 & Not modified \\
\hline Coolant filter,hsg,thermostat,pump & 86 & Not modified \\
\hline Oil cooler, filter, \& oil pump & 53 & Not modified \\
\hline Turbocharger \& manifold & 64 & Not modified \\
\hline Control module & 11 & Not modified \\
\hline Starter & 39 & Not modified \\
\hline TOTAL & $\mathbf{2 0 2 8}$ & $\mathbf{1 5 9 2}$ \\
\hline & & \\
\hline
\end{tabular}

It was found that a 22-percent weight reduction could be achieved if the engine's largest cast iron and steel components were converted to aluminum and titanium. If the cylinder head of the engine had already been made of aluminum, only a 16-percent total weight reduction would have been possible. The weight reduction is shown graphically in Figure C-1 below. 


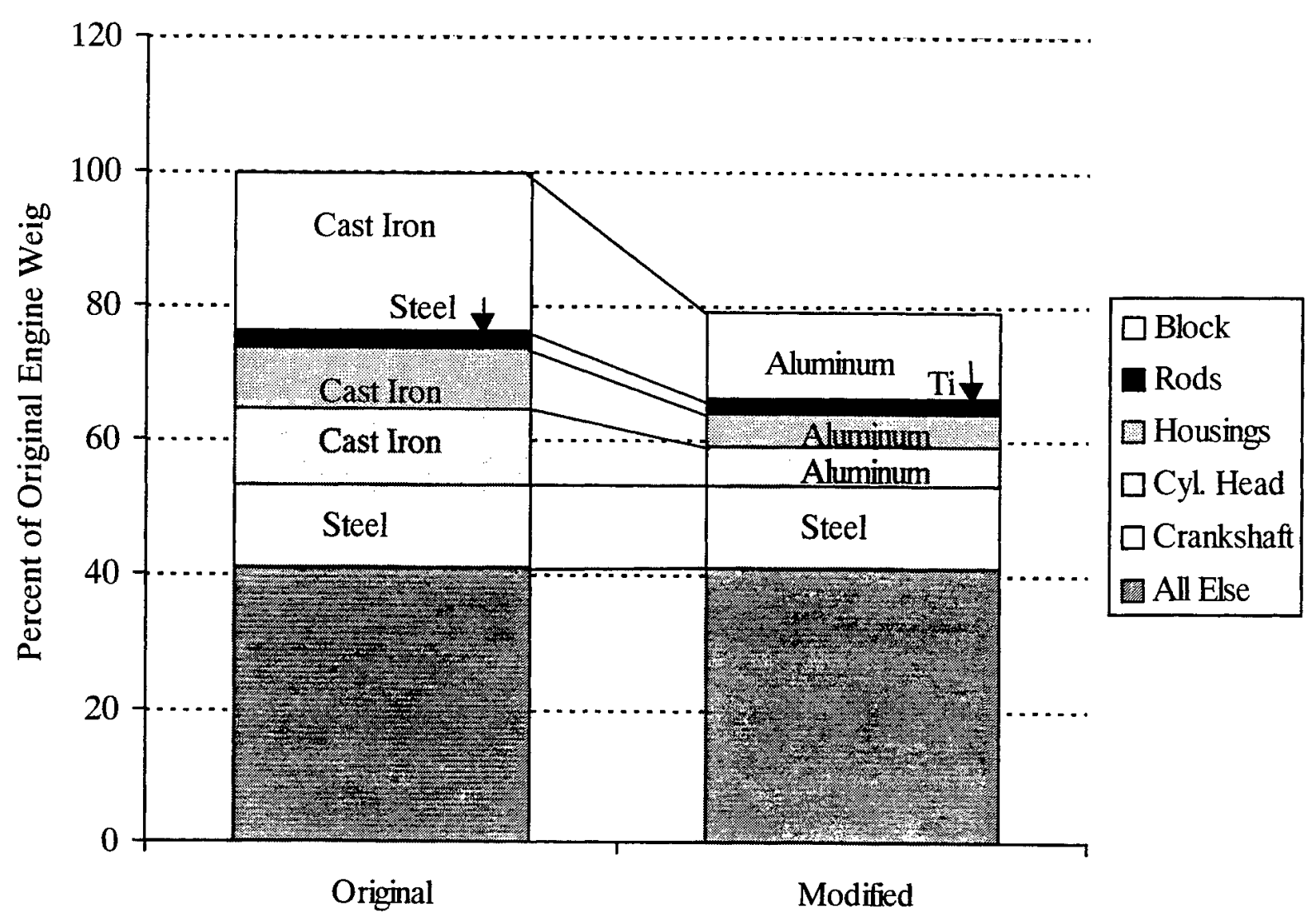

Figure C-1. Weight Reduction of Cummins M11 Engine 


\section{APPENDIX D}

Development of Commercially Based Engine Family

D-1 
An engine family consists of several engines with the same power section (cylinder, piston, head, connecting rod, fuel-injection equipment) but differing numbers of cylinders. The output power from different numbers of cylinders was determined using Equations (1) and (2) from Appendix B.

The bore diameter designed for the family was estimated from PNGV preliminary design data. A piston speed of 2300 feet per minute and a bore/stroke ratio of 1 were assumed. The engine has a four-stroke cycle. This information was used to develop the following plot.

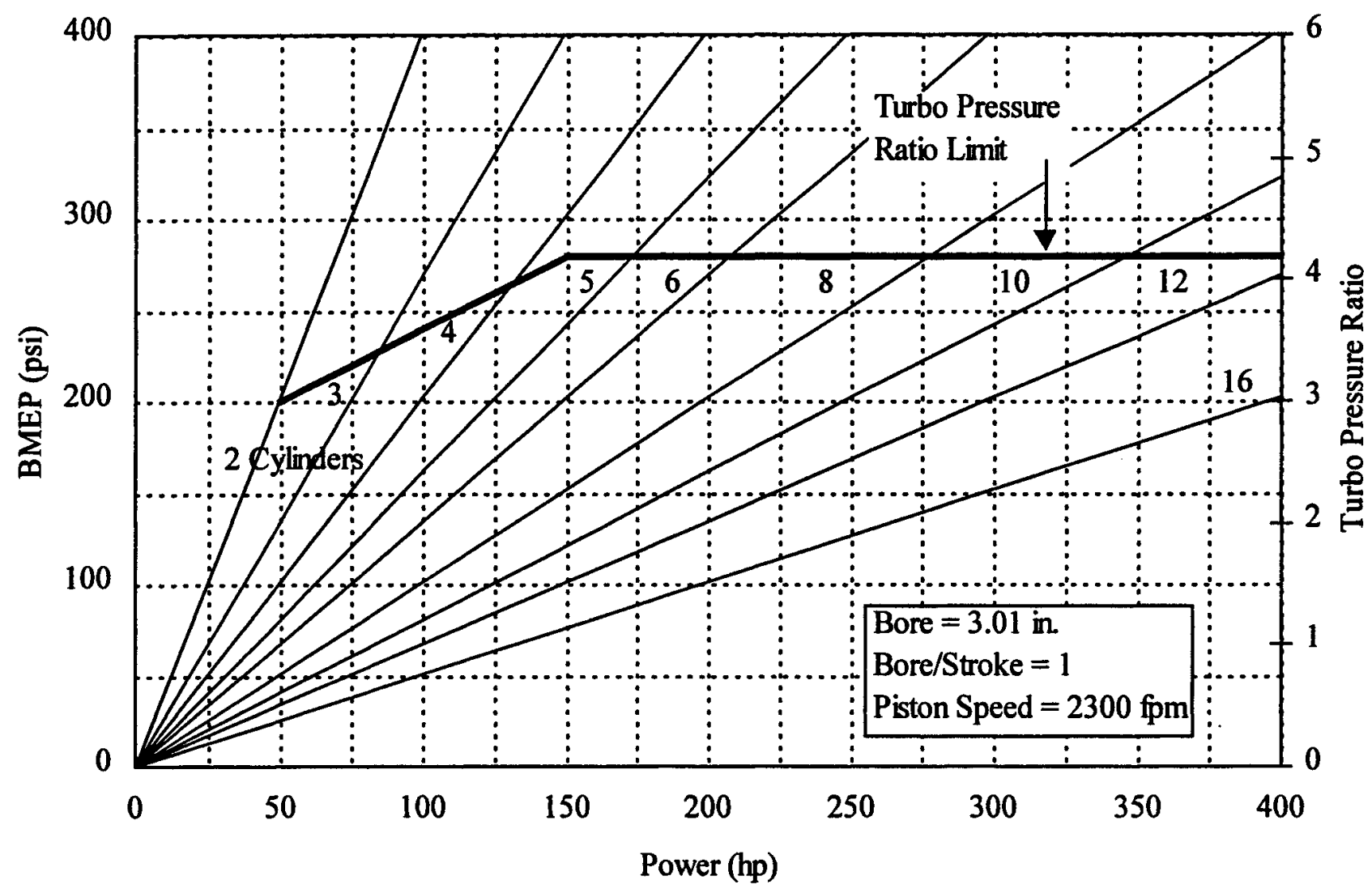

Figure D-1. Plot of Commercially Based Engine Family

This plot can be used to determine the number of cylinders and BMEP required to develop the horsepower output for each DoD application. BMEP is limited by the maximum available turbocharger pressure ratio, which is also shown on the plot. For example, if a $150 \mathrm{hp}$ engine is needed, enter the horizontal axis at $150 \mathrm{hp}$ and move vertically upwards. Intersections with the slanted lines define engine configurations that will produce $150 \mathrm{hp:} 16$ cylinders at $75 \mathrm{psi}$ BMEP, 12 cylinders at $100 \mathrm{psi}$ BMEP, 10 at 120,8 at 150,6 at 200, and 5 cylinders at about 245 psi BMEP. One cannot exceed the 
BMEP defined by the turbo pressure limit. All of these engines are solutions, but the lightest engine is the one at the highest BMEP. In the report, all of the engines chosen for the family are those with the highest BMEP. If BMEP levels chosen for any particular engine are thought to be excessive, the BMEP can be decreased and the number of cylinders increased, and the engine weight will increase.

In the table below, the number of cylinders and maximum BMEP is shown for the 16 DoD applications not satisfied by commercial engines.

\begin{tabular}{|l|l|l|l|l|l|}
\hline Table D-1. Commercially-Based Engine Family \\
\hline & $\begin{array}{l}\text { Specified } \\
\text { Power } \\
\text { (bhp) }\end{array}$ & $\begin{array}{l}\text { Specified } \\
\text { Specific Wt. } \\
\text { (lb/hp) }\end{array}$ & $\begin{array}{l}\text { Resulting } \\
\text { No. of } \\
\text { Cyl. }\end{array}$ & $\begin{array}{l}\text { Resulting } \\
\text { BMEP } \\
\text { (psi) }\end{array}$ & $\begin{array}{l}\text { Resulting } \\
\text { Specific } \\
\text { Wt. (lb/hp) }\end{array}$ \\
\hline UAV-High Endurance & 120 & 1.67 & 4 & 245 & 1.34 \\
\hline UAV-Short Endurance & 60 & 1.33 & 3 & 165 & 1.99 \\
\hline RSTV & 136 & 2.21 & 5 & 220 & 1.46 \\
\hline CHPS & 300 & 2.33 & 10 & 240 & 1.34 \\
\hline Motorcycle & 40 & 1.88 & 2 & 165 & 1.99 \\
\hline Snowmobile & 50 & 2.00 & 2 & 200 & 1.64 \\
\hline Outboard & 50 & 2.00 & 2 & 200 & 1.64 \\
\hline Ship Fire Pump & 30 & 1.5 & 2 & 125 & 2.63 \\
\hline Small Truck (hybrid) & 136 & 2.21 & 5 & 220 & 1.46 \\
\hline Medium Truck (hybrid) & 200 & 3.00 & 6 & 270 & 1.22 \\
\hline HMMVW & 180 & 2.50 & 6 & 240 & 1.37 \\
\hline FAV & 160 & 1.56 & 5 & 260 & 1.26 \\
\hline RHIB Boat & 400 & 3.00 & 12 & 270 & 1.24 \\
\hline APU-10kW & 24 & 3.96 & 2 & 95 & 3.65 \\
\hline APU-30kW & 66 & 3.03 & 3 & 180 & 1.82 \\
\hline APU-60kW & 132 & 3.03 & 5 & 215 & 1.56 \\
\hline
\end{tabular}

For each application, $B M E P$ and $N$ (from piston speed and stroke) are known. The minimum feasible volume-specific weight, VSW, was estimated from data on commercial diesel engines (see Appendix E). Equation (5) from Appendix B was then solved for specific weight. In three cases in the table above (italicized), the specific weight of our engine design is higher than the DoD-specified value. Therefore, these three engines will not fit into this engine family. 
APPENDIX E

Current Diesel Engine Technology

E-1 
Commercial engine data from two databases was used throughout this project. The first database was developed by the SwRI Engine Design Department. Data from the second was commercially available to SwRI from Power Systems, Inc. The data was used to find commercial engines that could be modified to fit DoD applications. It was also used to gain insight into engine characteristics of today's diesel engines.

The following plots were developed as tools for analyzing the data. All engines with bore diameters less than 3.5 in. are plotted; larger engines were not plotted because they are too large to be relevant to this study. Following the plots is a table with information relating to some of the most notable engines shown on the plots. 


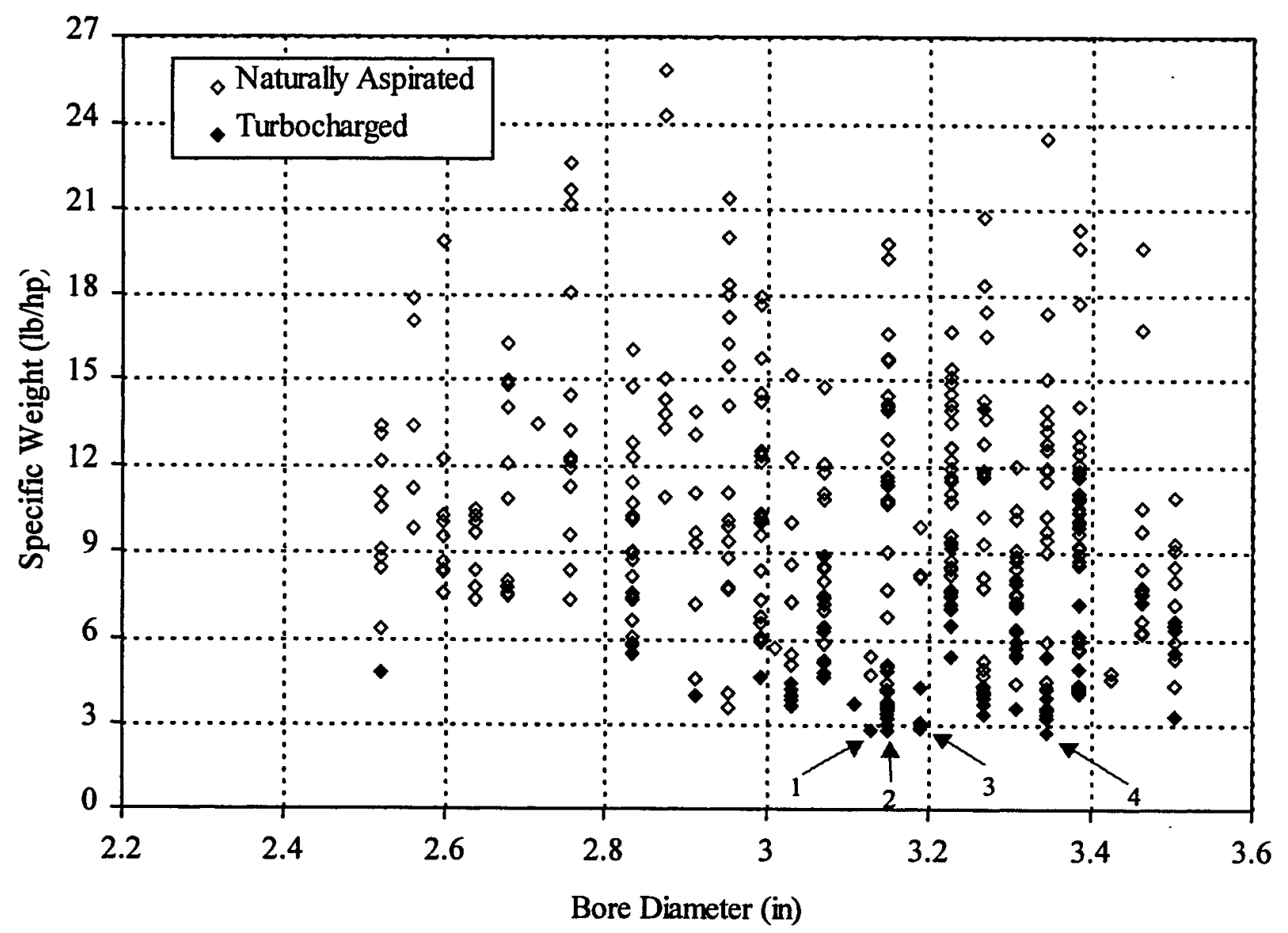

Figure E-1. Specific Weight vs. Bore Diameter

From this plot, it was determined that the minimum specific weight available in a commercial engine is $2.8 \mathrm{lb} / \mathrm{hp}$. In Table E-1, engines 1 and 3 from the plot above are listed as having aluminum cylinder heads. If light alloys were also used for the cylinder block, housings, and rods, a 16-percent weight reduction would be possible. Additionally, with additional turbocharging, the power output could be increased by 25 percent. Overall this leads to a $1.9 \mathrm{lb} / \mathrm{hp}$ minimum achievable specific weight. The cylinder head material of engines 2 and 4 is not known. If it is cast iron, the weight reduction can be 22 percent, resulting in a specific weight of $1.7 \mathrm{lb} / \mathrm{hp}$ 


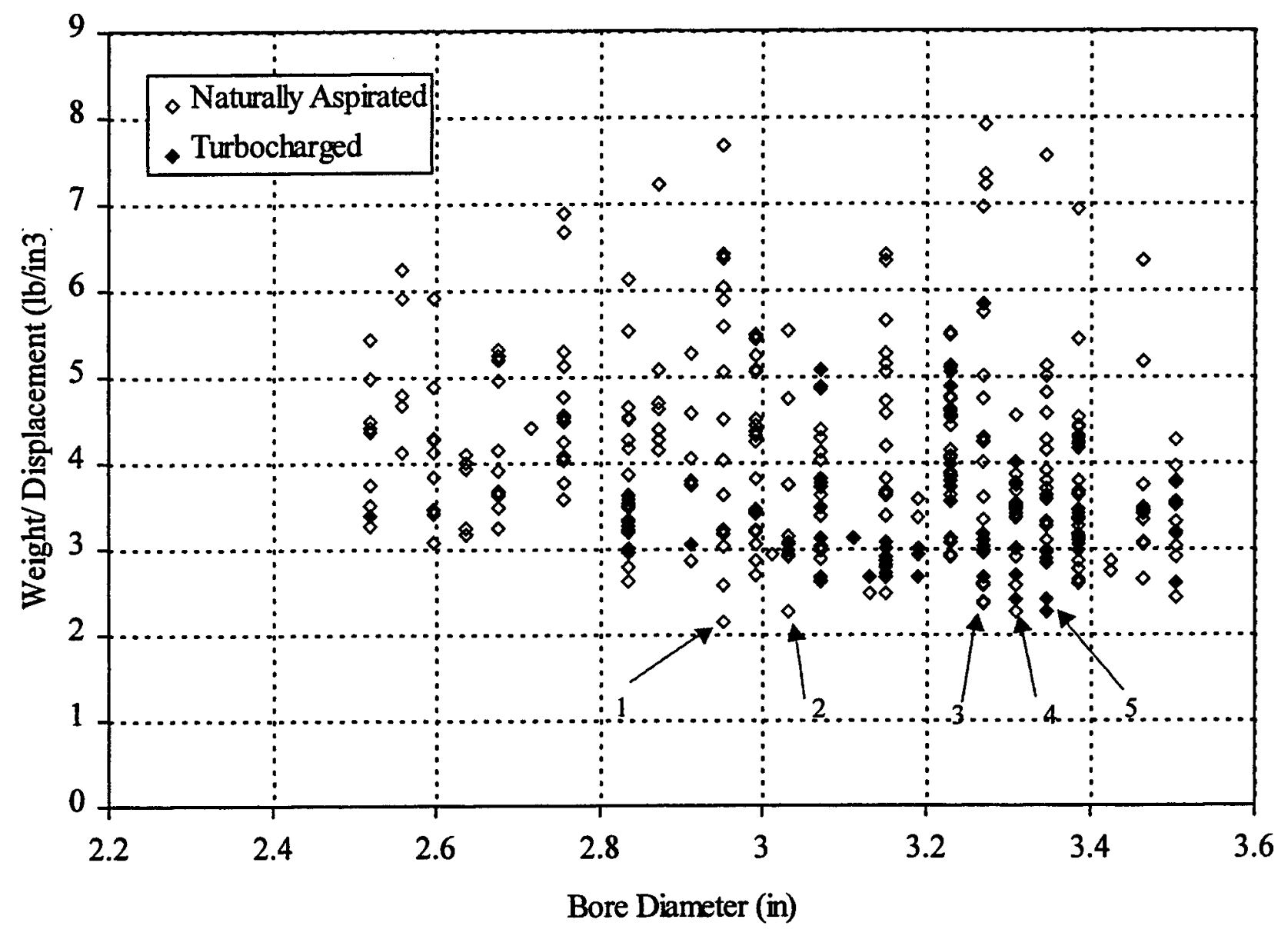

Figure E-2. Volume-Specific Weight vs. Bore Diameter

This plot was used to determine the minimum volume-specific weight that is currently available commercially; i.e., $2.3 \mathrm{lb} / \mathrm{in}^{3}$. However, with a 16-percent weight reduction (for an engine that already has an aluminum cylinder head), this could be reduced to 1.9 $\mathrm{lb} / \mathrm{in}^{3}$. With a 22-percent weight reduction (for an engine that has a cast iron cylinder head), this could be reduced further to $1.7 \mathrm{lb} / \mathrm{in}^{3}$. 


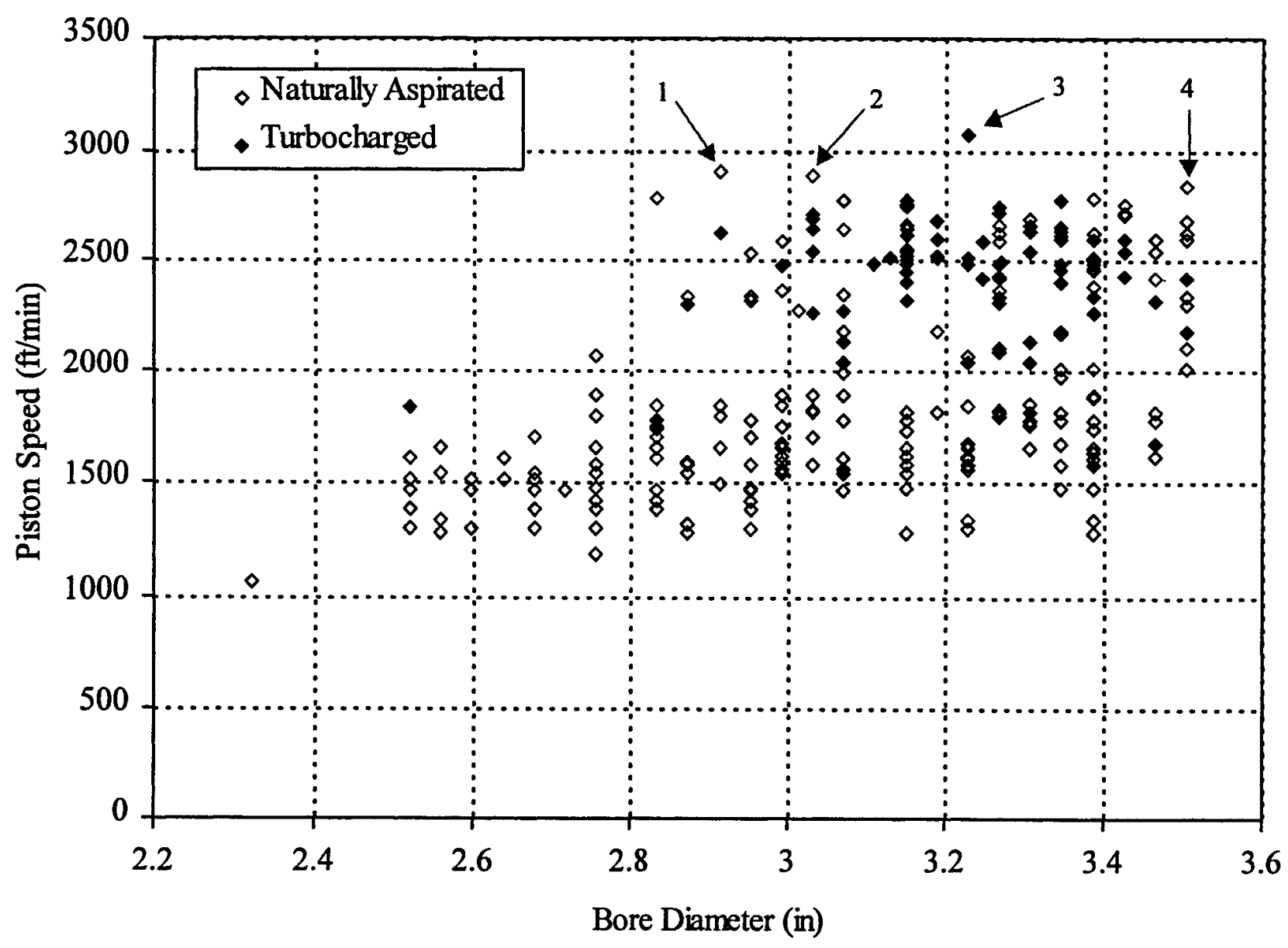

Figure E-3. Piston Speed at Rated Horsepower vs. Bore Diameter

This plot was used to determine feasible piston speeds. These engines reach speeds up to $2800 \mathrm{fpm}$ (not counting a few anomalous points). Nevertheless, we chose a value of $2300 \mathrm{fpm}$ for our engine families for some margin in durability. 


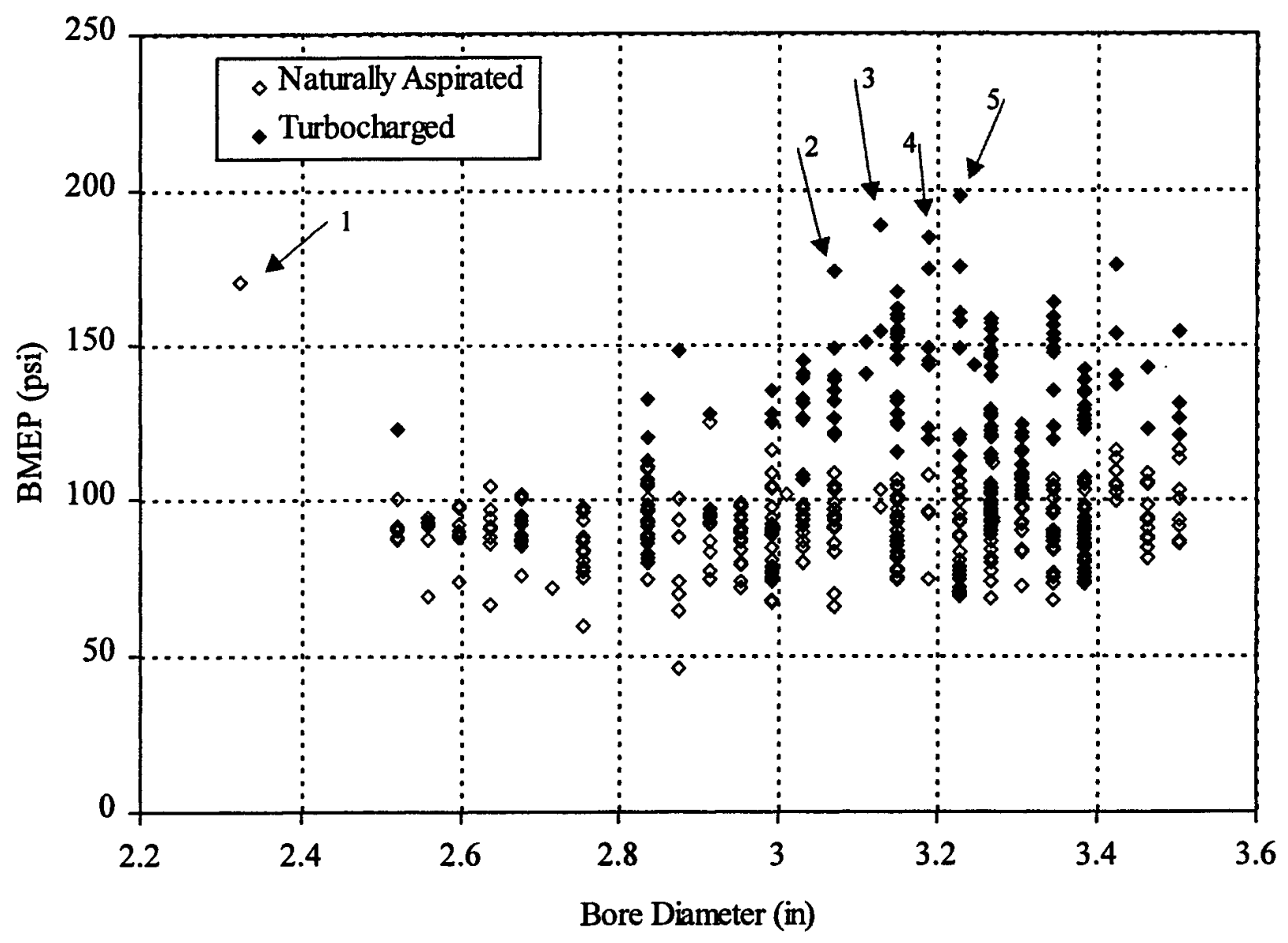

Figure E-4. Brake Mean Effective Pressure (BMEP) at Rated Horsepower vs. Bore Diameter

This plot shows that at rated horsepower, the BMEP of most diesel engines is less than $150 \mathrm{psi}$, although there are some engines with higher BMEP's, ranging from 150 to 180 psi. 


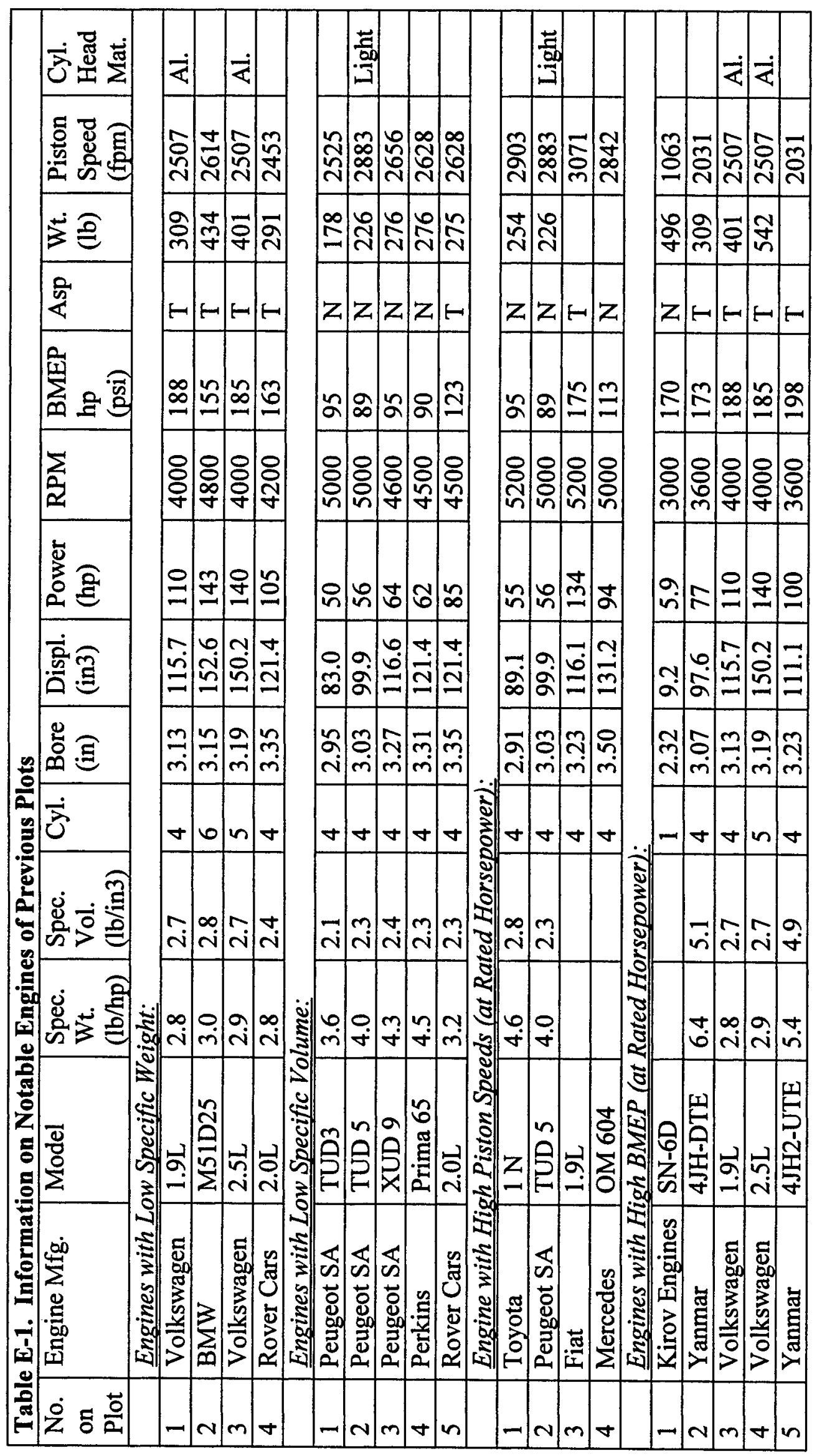


APPENDIX F

Development of DOD-Specific Engine Family

F-1 
The development of this engine family proceeded as described in Appendix D for the commercially based engine family. Again, a piston speed of $2300 \mathrm{fpm}$ and a bore/stroke ratio of 1 were assumed. A smaller bore diameter of 2.75 in. was used for this family.

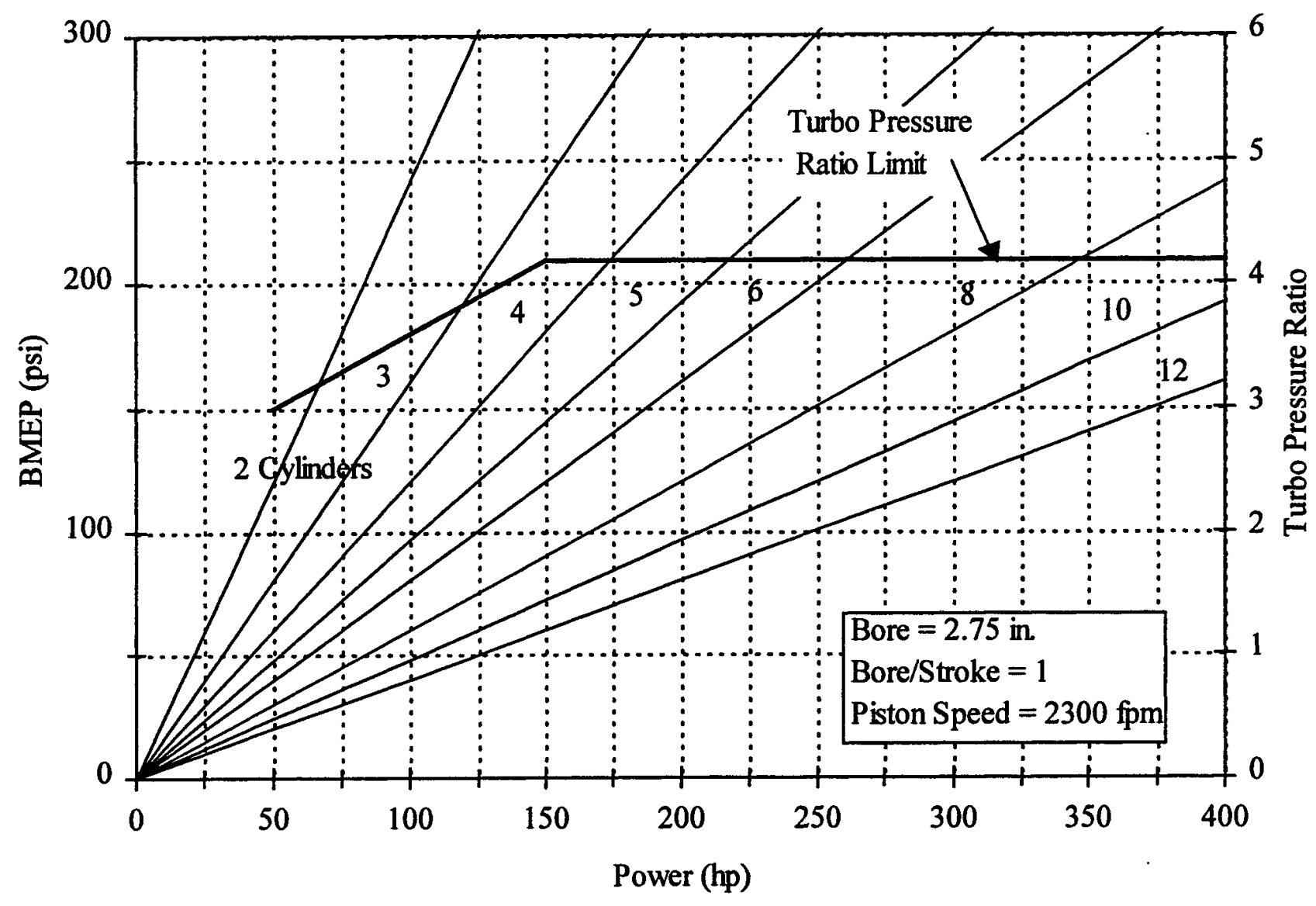

Figure F-1. Plot of DoD-Specific Engine Family

In addition, since this is a two-cycle engine family, the minimum volume-specific weight was assumed to be lower. Since no data was available for very small two-cycle diesel commercial engines, the value of $1.42 \mathrm{lb} / \mathrm{in}^{3}$ was assigned to specific volume based on estimation of the weight reduction achievable using a two-cycle engine instead of a fourcycle engine. The resulting specific weights of this family are within the limits specified by DoD. 


\begin{tabular}{|l|l|l|l|l|l|}
\hline Table F-1. DoD-Specific Engine Family \\
\hline & $\begin{array}{l}\text { Specified } \\
\text { Power } \\
(\mathrm{bhp})\end{array}$ & $\begin{array}{l}\text { Specified } \\
\text { Specific Wt. } \\
(\mathrm{lb} / \mathrm{hp})\end{array}$ & $\begin{array}{l}\text { Resulting } \\
\text { No. of } \\
\text { Cyl. }\end{array}$ & $\begin{array}{l}\text { Resulting } \\
\text { BMEP } \\
\text { (psi) }\end{array}$ & $\begin{array}{l}\text { Resulting } \\
\text { Specific } \\
\text { Wt. (lb/hp) }\end{array}$ \\
\hline UAV-High Endurance & 120 & 1.67 & 3 & 195 & 0.59 \\
\hline UAV-Short Endurance & 60 & 1.33 & 2 & 145 & 0.75 \\
\hline Motorcycle & 40 & 1.88 & 2 & 100 & 1.12 \\
\hline Ship Fire Pump & 30 & 1.5 & 2 & 75 & 1.5 \\
\hline
\end{tabular}




\section{Fuels Distribution List}

\section{Department of Defense}

DEFENSE TECH INFO CTR

ATTN: DTIC OCC

8725 JOHN J KINGMAN RD

STE 0944

FT BELVOIR VA 22060-6218

ODUSD

ATTN: (L) MRM

PETROLEUM STAFF ANALYST

PENTAGON

WASHINGTON DC 20301-8000

ODUSD

ATTN: (ES) Cl

400 ARMY NAVY DR

STE 206

ARLINGTON VA 22202

HQ USEUCOM

ATTN: ECJU L1J

UNIT 30400 BOX 1000

APO AE 09128-4209

US CINCPAC

ATTN: J422 BOX 64020

CAMP H M SMITH

HI 96861-4020
12

JOAP TSC

BLDG 780

NAVAL AIR STA

PENSACOLA FL 32508-5300

DIR DLA

ATTN: DLA MMSLP

18725 JOHN J KINGMAN RD

STE 2533

FT BELVOIR VA 22060-6221

CDR

DEFENSE FUEL SUPPLY CTR

1 ATTN: DFSC I (C MARTIN)

DFSC IT (R GRAY)

DFSC IQ (L OPPENHEIM)

8725 JOHN J KINGMAN RD

STE 2941

FT BELVOIR VA 22060-6222

1

DIR

DEFENSE ADV RSCH PROJ AGENCY

ATTN: ARPA/ASTO

3701 N FAIRFAX DR

1 ARLINGTON VA 22203-1714
1

1

1

1

\section{Department of the Army}

HQDA

ATTN: DALO TSE DALO SM

500 PENTAGON

WASHINGTON DC 20310-0500

SARDA

ATTN: SARD TT

PENTAGON

WASHINGTON DC 20310-0103

CDR AMC

ATTN: AMCRD S

AMCRD E

AMCRD IT

AMCEN A

AMCLG M

AMXLSH

5001 EISENHOWER AVE

ALEXANDRIA VA 22333-0001

U.S. ARMY TACOM

TARDEC PETR. \& WTR. BUS. AREA

ATTN AMSTA TR-D/210 (L. VILLHAHERMOSA) 10 AMSTA TR-D/210 (T. BAGWELL) 1

WARREN, MI 48397-5000
CDR ARMY TACOM

ATTN: AMSTA IM LMM

AMSTA IM LMB

AMSTA IM LMT

AMSTA TR NAC MS 002

AMSTA TR R MS 202

AMSTA TR D MS 201A

AMSTA TR M

AMSTA TR R MS 121 (C RAFFA)

AMSTA TR R MS 158 (D HERRERA)

AMSTA TR R MS 121 (R MUNT)

AMCPM ATP MS 271

AMSTA TR E MS 203

AMSTA TR K

AMSTA IM KP

AMSTA IM MM

AMSTA IM MT

AMSTA IM MC

AMSTA IM GTL

AMSTA CL NG

USMC LNO

AMCPM LAV

AMCPM M113

AMCPM CCE

WARREN MI 48397-5000 


\section{Department of the Army}

PROG EXEC OFFICER

ARMORED SYS MODERNIZATION

ATTN: SFAE ASM S

SFAE ASM H

SFAE ASM AB

SFAE ASM BV

SFAE ASM CV

CDR TACOM

SFAE ASM AG

WARREN MI 48397-5000

PROG EXEC OFFICER

ARMORED SYS MODERNIZATION

ATTN: SFAE FAS AL

SFAE FAS PAL

PICATINNY ARSENAL

NJ 07806-5000

PROG EXEC OFFICER

TACTICAL WHEELED VEHICLES

ATTN: SFAE TWV TVSP SFAE TWV FMTV SFAE TWV PLS

CDR TACOM

WARREN MI 48397-5000

PROG EXEC OFFICER

ARMAMENTS

ATTN: SFAE AR HIP SFAE AR TMA

PICATINNY ARSENAL

NJ 07806-5000

PROG MGR

UNMANNED GROUND VEH

ATTN: AMCPM UG

REDSTONE ARSENAL

AL 35898-8060

DIR

ARMY RSCH LAB

ATTN: AMSRL PB P

2800 POWDER MILL RD

ADELPHIA MD 20783-1145

VEHICLE PROPULSION DIR

ATTN: AMSRL VP (MS 77 12)

NASA LEWIS RSCH CTR

21000 BROOKPARK RD

CLEVELAND OH 44135

CDR AMSAA

ATTN: AMXSY CM AMXSY L

APG MD 21005-5071

CDR ARO

ATTN: AMXRO EN (D MANN)

RSCH TRIANGLE PK

NC 27709-2211

TFLRF No. 331

Page 2 of 5
CDR AEC

ATTN: SFIM AEC ECC (T ECCLES) 1

APG MD 21010-5401

CDR ARMY ATCOM

ATTN: AMSAT I WM

AMSAT I ME (L HEPLER)

AMSAT I LA (V SALISBURY)

AMSAT R EP (V EDWARD)

4300 GOODFELLOW BLVD

ST LOUIS MO 63120-1798

CDR ARMY SOLDIER SPT CMD

1 ATTN: SATNC US (J SIEGEL)

1 SATNC UE

NATICK MA 01760-5018

CDR ARMY ARDEC

ATTN: AMSTA AR EDE S

1

PICATINNY ARSENAL

1 NJ 07808-5000

1

1 CDR ARMY WATERVLIET ARSN

ATTN: SARWY RDD

1

WATERVLIET NY 12189

CDR APC

ATTN: SATPC L

SATPC Q

NEW CUMBERLAND PA 17070-5005

CDR ARMY LEA

ATTN: LOEA PL

NEW CUMBERLAND PA 17070-5007

1 CDR ARMY TECOM

ATTN: AMSTE TA R

AMSTE TC D

AMSTE EQ

APG MD 21005-5006

1 PROJ MGR PETROL WATER LOG

ATTN: AMCPM PWL

4300 GOODFELLOW BLVD

ST LOUIS MO 63120-1798

1 PROJ MGR MOBILE ELEC PWR

ATTN: AMCPM MEP T

AMCPM MEP L

7798 CISSNA RD STE 200

SPRINGFIELD VA 22150-3199

CDR

ARMY COLD REGION TEST CTR

ATTN: STECR TM

STECR LG

APO AP 96508-7850

1
1
1
1

1

1

1 


\section{Department of the Army}

CDR

ARMY BIOMED RSCH DEV LAB

ATTN: SGRD UBZ A

FT DETRICK MD 21702-5010

CDR FORSCOM

ATTN: AFLG TRS

FT MCPHERSON GA $30330-6000$

CDR TRADOC

ATTN: ATCD SL 5

INGALLS RD BLDG 163

FT MONROE VA 23651-5194

CDR ARMY ARMOR CTR

ATTN: ATSB CD ML ATSB TSM T

FT KNOX KY 40121-5000

CDR ARMY QM SCHOOL

ATTN: ATSM PWD

FT LEE VA 23001-5000

ARMY COMBINED ARMS SPT CMD

ATTN: ATCL CD

ATCL MS

ATCL MES (C PARENT)

FT LEE VA 23801-6000

CDR ARMY FIELD ARTY SCH

ATTN: ATSF CD

FT SILL OK 73503

CDR ARMY TRANS SCHOOL

ATTN: ATSP CD MS

FT EUSTIS VA $23604-5000$

CDR ARMY INF SCHOOL

ATTN: ATSH CD

ATSH AT

FT BENNING GA 31905-5000

CDR ARMY AVIA CTR

ATTN: ATZQ DOL M ATZQ DI

FT RUCKER AL 36362-5115

CDR ARMY ENGR SCHOOL

ATTN: ATSE CD

FT LEONARD WOOD

MO $65473-5000$
CDR ARMY SAFETY CTR

ATTN: CSSC PMG

CSSC SPS

1

FT RUCKER AL 36362-5363

CDR ARMY ABERDEEN TEST CTR

ATTN: STEACEN

STEAC LI

STEAC AE

STEAC AA

1 APG MD 21005-5059

CDR ARMY YPG

ATTN: STEYP MT TL M

YUMA AZ 85365-9130

CDR ARMY CERL

ATTN: CECER EN

P O BOX 9005

CHAMPAIGN IL 61826-9005

1

DIR

AMC FAST PROGRAM

10101 GRIDLEY RD STE 104

FT BELVOIR VA 22060-5818

CDR I CORPS AND FT LEWIS

ATTN: AFZH CSS

FT LEWIS WA $98433-5000$

CDR

1 RED RIVER ARMY DEPOT

ATTN: SDSRR M

SDSRR Q

TEXARKANA TX 75501-5000

1

PS MAGAZINE DIV

ATTN: AMXLSPS

DIR LOGSA

1 REDSTONE ARSENAL AL $35898-7466$

CDR 6TH ID (L)

ATTN: APUR LGM

1060 GAFFNEY RD

FT WAINWRIGHT AK 99703

CDR ARMY ORDN CTR

ATTN: ATSL CD CS

APG MD 21005

CDR 49TH QM GROUP

ATTN: AFFL GC

FT LEE VA 23801-5119
1

1

1

1

1

1

1

1 


\section{Department of the Navy}

OFC CHIEF NAVAL OPER

ATTN: DR A ROBERTS (N420)

2000 NAVY PENTAGON

WASHINGTON DC 20350-2000

CDR

NAVAL SEA SYSTEMS CMD

ATTN: SEA $03 M 3$

2531 JEFFERSON DAVIS HWY

ARLINGTON VA 22242-5160

CDR

NAVAL SURFACE WARFARE CTR

ATTN: CODE 63

CODE 632

CODE 859

3A LEGGETT CIRCLE

ANNAPOLIS MD 21402-5067

CDR

NAVAL RSCH LABORATORY

ATTN: CODE 6181

WASHINGTON DC 20375-5342
CDR

1 NAVAL AIR WARFARE CTR

ATTN: CODE PE33 AJD

PO BOX 7176

TRENTON NJ 08628-0176

CDR

1 NAVAL PETROLEUM OFFICE

8725 JOHN J KINGMAN RD

STE 3719

FT BELVOIR VA 22060-6224

CDR

1 NAVAL AIR SYSTEMS CMD

1 ATTN: AIR 4.4.5 (D MEARNS)

11421 JEFFERSON DAVIS HWY

ARLINGTON VA 22243-5360

\section{Department of the Navy/U.S. Marine Corps}

HQ USMC

ATTN: LPP

WASHINGTON DC 20380-0001

PROG MGR COMBAT SER SPT

MARINE CORPS SYS CMD

2033 BARNETT AVE STE 315

QUANTICO VA 22134-5080

PROG MGR GROUND WEAPONS

MARINE CORPS SYS CMD

2033 BARNETT AVE

QUANTICO VA 22134-5080

PROG MGR ENGR SYS

MARINE CORPS SYS CMD

2033 BARNETT AVE

QUANTICO VA 22134-5080

CDR

MARINE CORPS SYS CMD

ATTN: SSE

2030 BARNETT AVE STE 315

QUANTICO VA 22134-5010
CDR

1 BLOUNT ISLAND CMD

ATTN: CODE 922/1

5880 CHANNEL VIEW BLVD

1 JACKSONVILLE FL 32226-3404

CDR

ATTN: CODE 837

814 RADFORD BLVD

1 ALBANY GA $31704-1128$

CDR

2ND MARINE DIV

1 PSC BOX 20090

CAMP LEJEUNNE

NC 28542-0090

CDR 1

FMFPAC G4

BOX 64118

1 CAMP H M SMITH

HI 96861-4118
1 


\section{Department of the Air Force}

HQ USAF/LGSF

ATTN: FUELS POLICY

1030 AIR FORCE PENTAGON

WASHINGTON DC 20330-1030

HQ USAF/LGTV

ATTN: VEH EQUIP/FACILITY 1030 AIR FORCE PENTAGON

WASHINGTON DC 20330-1030

AIR FORCE WRIGHT LAB

ATTN: WLIPOS

WLIPOSF

1790 LOOP RD N

WRIGHT PATTERSON AFB

$\mathrm{OH}$ 45433-7103

AIR FORCE MEEP MGMT OFC OL ZC AFMC LSO/LOT PM

201 BISCAYNE DR

BLDG 613 STE 2

ENGLIN AFB FL 32542-5303
SA ALC/SFT

1

1014 BILLY MITCHELL BLVD STE 1

KELLY AFB TX 78241-5603

1 ATTN: D ELLIOTT

580 PERRIN BLDG 329

KELLY AFB TX 78241-6439

WR ALC/LVRS

225 OCMULGEE CT

ROBINS AFB

GA 31098-1647

\section{Other Federal Agencies}

NASA

LEWIS RESEARCH CENTER

CLEVELAND OH 44135

RAYMOND P. ANDERSON, PH.D., MANAGER FUELS \& ENGINE TESTING

BDM-OKLAHOMA, INC.

220 N. VIRGINIA

BARTLESVILLE OK 74003

DOT

FAA

AWS 110

800 INDEPENDENCE AVE SW

WASHINGTON DC 20590
DOE

CE 151 (MR RUSSELL)

11000 INDEPENDENCE AVE SW

WASHINGTON DC 20585

1 EPA

AIR POLLUTION CONTROL

2565 PLYMOUTH RD

ANN ARBOR MI 48105 